\title{
Bioaccumulation and transfer of benzo(a)pyrene in a simplified marine food chain
}

\author{
Xinhong Wang, Wen-Xiong Wang*
}

Department of Biology, The Hong Kong University of Science and Technology (HKUST), Clear Water Bay, Hong Kong, SAR

\begin{abstract}
We examined the toxicokinetics of benzo(a)pyrene (BaP) and the trophic transfer in a marine planktonic food chain comprising phytoplankton, copepods, and fish. Kinetic parameters including the uptake rate from the dissolved phase, the assimilation efficiency $(A E)$ from the ingested food, and the elimination rate were quantified. Influences of food quality and quantity and different routes of exposure (aqueous and food) on the biokinetics were also examined. The uptake rate constants were 390 to $1090 \mathrm{ml} \mathrm{mg}^{-1} \mathrm{~h}^{-1}$ in different species of phytoplankton, $1.2 \mathrm{ml} \mathrm{mg}^{-1} \mathrm{~h}^{-1}$ in the copepods, and $0.157 \mathrm{ml} \mathrm{mg}^{-1} \mathrm{~h}^{-1}$ in the fish, respectively. The assimilation efficiencies were 2 to $24 \%$ in the copepods and 32 to $51 \%$ in the fish ingesting different prey types. Increasing food concentration significantly reduced the $A E \mathrm{~s}$, whereas the $A E \mathrm{~s}$ varied little among the different food diets tested at the same biomass. The elimination rate constants by the copepods were 0.8 to $1.7 \mathrm{~d}^{-1}$, and comparable following uptake from the aqueous phase and the dietary phase. A kinetic modeling calculation suggests that more BaP accumulated in the copepods originates from the dietary intake than the aqueous intake. For fish, both trophic transfer and aqueous uptake are important in BaP bioaccumulation. Feeding rates contribute to the differences in the relative proportion of accumulated BaP in the fish.
\end{abstract}

KEY WORDS: PAHs $\cdot$ Bioaccumulation $\cdot$ Kinetic modeling $\cdot$ Food chain

\section{INTRODUCTION}

Many toxic xenobiotic compounds are eventually discharged into the sea, accumulated and transferred in the marine food chains. Polycyclic aromatic hydrocarbons (PAHs) are carcinogenic and mutagenic compounds with considerable potential of biotransformation and can result in significant adverse health and environmental effects (Neff 2002). Elevated levels of PAHs have been detected in numerous coastal environments (Connell et al. 1998, Fisk et al. 2001, Klumpp et al. 2002, Maskaoui et al. 2002, Moore et al. 2002). Sources of PAHs in marine environment are usually related to human activities such as petroleum discharge or atmospheric deposition of incomplete combustion materials.

The bioaccumulation of PAHs by marine organisms has been extensively studied (van der Oost et al. 1991, Hellou et al. 1995, Meador et al. 1995, Kane \& McElroy 1996, D'Adamo et al. 1997, Klosterhaus et al.
2002). However, the majority of laboratory and field studies focused on the uptake from water and the relationship between the bioconcentration factor $(B C F$, the ratio of contaminant concentration in an organism to the dissolved concentration) and the octanol-water partition coefficient $\left(\mathrm{K}_{\mathrm{ow}}\right)$. Barron (1990) indicated that the bioconcentration of PAHs from solution by marine organisms was directly proportional to their $\mathrm{K}_{\mathrm{ow}}$. The quantified $B C F$ increased with the $\mathrm{K}_{\mathrm{ow}}$ or molecular weight of PAHs (Veith \& Kosian 1983), but the BCFs quantified in the field varied from those predicted simply from the $\mathrm{K}_{\mathrm{ow}}$ (Zaroogian et al. 1985, Neff \& Burns 1996), suggesting that trophic transfer may also be important in the accumulation of these PAH compounds. Because of the biotransformation of PAHs by the mixed-function oxygenases (or oxidases) (MFOs), the PAHs can be converted to arene oxide intermediates followed by formation of derivatives of transdihydrodiols, phenols, and quinines, and are finally excreted. 
Phytoplankton organisms are the primary producers in the aquatic systems and therefore play a key role in the transport of organic contaminants to higher trophic levels. Marine copepods are the link between the primary producers and the higher trophic level such as fish, thus uptake by zooplankton presents another redistribution pathway for organic contaminants in the marine food chains. The bioaccumulation of PAHs by zooplankton has been considered in only a few early studies (Corner et al. 1976, Harris et al. 1977a,b). Fundamental processes of $\mathrm{PAH}$ transport in the lower trophic food chain need to be better understood to enable prediction of the environmental fate and food chain transport in the ecosystem of concern.

In this study, we examined the bioaccumulation and trophic transfer of benzo(a)pyrene (BaP, a 5 ring $\mathrm{PAH}$ compound) in a marine food chain consisting of phytoplankton, copepods and fish. We measured the uptake from the dissolved phase, the assimilation efficiency from the lower trophic level, and the elimination of BaP in the animals. After these experimental measurements, we constructed a simple food chain kinetic model to estimate the relative importance of aqueous and dietary exposure. The kinetic model has been used to evaluate the bioaccumulation of contaminants and to quantify the bioaccumulation factor (Landrum et al. 1992, Wang et al. 1996). With this model, the physiological process controlling contaminant accumulation can be identified and measured under varying environment conditions. It is also possible to predict the trophic transfer factor based on the kinetic measurements of contaminant uptake and elimination in the animals.

\section{MATERIALS AND METHODS}

Chemicals and organisms. ${ }^{3} \mathrm{H}$-benzo(a)pyrene (with a specific activity of $48 \mathrm{Ci} \mathrm{mmol}^{-1}, \log \mathrm{K}_{\mathrm{ow}}=6.13$, from Amersham) was dissolved in toluene solution (200 $\mu \mathrm{l})$. Radiochemical purity determined by the HPLC on a Hypersil ODS column using a water:methanol gradient system was $>99 \%$. The chemicals were subsequently diluted $100 \times$ in acetone to facilitate their solubility in seawater (solvent-to-seawater ratio <0.04\%). Preliminary experiments demonstrated that a trace amount of acetone in seawater did not affect the test organisms, as shown by the antioxidation enzyme activities (X. H. Wang unpubl. data). Because only a small amount of toluene was added (i.e. 2 orders of magnitude less than the acetone or $0.0004 \%$ of the solvent:seawater ratio), any influence of toluene on BaP uptake was ignored in our study.

Different species of phytoplankton (diatom Thalassiosira pseudonana and T. weissflogii, prasinophyte Tetraselmis levis, and dinoflagellate Prorocentum min- imum) were cultured in the laboratory and maintained in an $f / 2$ medium (Guillard \& Ryther 1962) at $18^{\circ} \mathrm{C}$ and at a light illumination of $70 \mu \mathrm{mol}$ photon $\mathrm{m}^{-2} \mathrm{~s}^{-1}$ with a 14:10 h light:dark cycle. Copepods Acartia erythraea were collected by net tows (250 $\mu \mathrm{m}$ mesh size) from Port Shelter, Clear Water Bay, Hong Kong. The copepods were returned to the laboratory and transferred into 41 of glass fibre filtered (GF/F) seawater, and fed with the mixed algae. Mangrove snappers Lutjanus argentimaculatus, 2 to $3 \mathrm{~cm}$ length with a wet weight of 0.5 to $0.7 \mathrm{~g}$, were purchased from a local fish farm. The experimental seawater was collected from Clear Water Bay, Hong Kong, and was filtered through GF/F and $0.22 \mu \mathrm{m}$ polycarbonate membranes before use. All experiments were carried out in glass vials to minimize sorption of organic contaminants onto the experimental glasswares.

Kinetic uptake of BaP from the aqueous phase. We examined the kinetic uptake of BaP by 4 species of marine phytoplankton: Thalassiosira pseudonana $(3 \mathrm{H})$, T. weissflogii (Thala, for both logarithmic and stationary phase), Tetraselmis levis (Tetra), and Prorocent um minimum (Pro). When the cells reached the logarithmic or stationary (for T. weissflogii only) growth phase, they were filtered and resuspended in $100 \mathrm{ml}$ of $0.2 \mu \mathrm{m}$ filtered seawater (FSW) at a cell biomass of $1 \mathrm{mg} \mathrm{l}^{-1}$. The algae were then spiked with $0.02 \mu \mathrm{Ci}{ }^{3} \mathrm{H}-\mathrm{BaP}$ (1.1 $\mathrm{ng} \mathrm{l}^{-1}$ ) and then exposed under the dark condition. The spiked concentration was higher than those in clean waters, but was comparable to or lower than those measured in polluted environments such as the contaminated Chinese coastal waters (Neff 2002, Maskaoui et al. 2002). No nutrient was added to the solution. There were 3 replicates for each algal species. At 0.5, 1.0, 1.5 and $2.0 \mathrm{~h}$ of exposure, a $10 \mathrm{ml}$ sample was filtered onto 2 stacked $25 \mathrm{~mm}$ GF/F filters and rinsed with $5 \mathrm{ml}$ of FSW. The top filter retained the algae, while the bottom filter was used to calibrate the sorption of $\mathrm{BaP}$ during the filtration step. The algae were solubilized by Solvable (Perkin-Elmer) and the radioactivity was later determined by Wallace 1414 Liquid Scintillation Counter (LSC) using the external standard ratio method and corrected for background and quenching. Counting times were adjusted to yield a propagated counting error of $<2$ to $3 \%$. A $1 \mathrm{ml}$ water sample was also taken for measurements of radioactivity (including both the water and the algae). All uptake experiments were conducted under red light and cocktails were added immediately to minimize losses associated with evaporation and photo-oxidation. The dry weight concentration factor $(D C F)$ was calculated as the ratio of $\mathrm{BaP}$ concentration in algae to the BaP concentration in the water (dry wt per volume).

The copepods were placed in 3 replicated $200 \mathrm{ml}$ FSW containing $0.05 \mu \mathrm{Ci}^{3} \mathrm{H}-\mathrm{BaP}\left(1.3 \mathrm{ng} \mathrm{l}^{-1}\right)$, under the 
dark condition. At 1, 2, 4, and $8 \mathrm{~h}$ of exposure, a $1 \mathrm{ml}$ water sample was removed for measurement of the radioactivity. Afterwards, 20 copepods were removed from each replicate bottle, rinsed with GF/F seawater by placing them in non-radioactive seawater for 2 to 3 min. The copepods were then solubilized with Solvable and the radioactivity was quantified by LSC after adding the cocktails. The dry weights of the copepods were also quantified by drying the copepods overnight at $80^{\circ} \mathrm{C}$.

Individual mangrove snappers were placed in $4 \mathrm{l}$ FSW containing $1 \mu \mathrm{Ci}{ }^{3} \mathrm{H}-\mathrm{BaP}\left(1.3 \mathrm{ng} \mathrm{l}^{-1}\right)$ under the dark condition. At 1, 2, 3, and $4 \mathrm{~h}$, individual fish were taken from 3 replicated tanks and placed in nonradioactive seawater for $5 \mathrm{~min}$ to remove the loosely bound compounds. Any remaining water on the body surface was then blotted dry and the fish was immediately dissected into 3 body parts: gill, viscera, and remaining tissue. The wet weight of each body part was first determined and 0.5 to $1.0 \mathrm{ml}$ of Solvable was subsequently added to solubilize the tissues. After 1 more day when the tissues (gills, viscera, or remaining tissues) were solubilized, a $10 \mathrm{ml}$ cocktail was added and the radioactivity was counted. A $1 \mathrm{ml}$ water sample was also collected at each time point. The dry weight to wet weight ratio of each body part was determined from 10 dissected fish after drying the tissues at $80^{\circ} \mathrm{C}$ for $>1 \mathrm{~d}$ until a constant weight was reached.

Assimilation of BaP from the food. The assimilation efficiency $(A E)$ of $\mathrm{BaP}$ in the copepods was quantified by pulse-feeding the animals with radiolabeled phytoplankton, whereas the $A E$ in fish was quantified by feeding the animals with radiolabeled copepods. The phytoplankton were first filtered from their growth medium, suspended into $200 \mathrm{ml} \mathrm{FSW}$, and spiked with ${ }^{3} \mathrm{H}-\mathrm{BaP}$. No nutrient was added to the medium. After $2 \mathrm{~h}$ in the dark, the cells were collected by centrifugation twice $\left(20 \mathrm{~min}, 2500 \times \mathrm{g}\right.$ at $\left.10^{\circ} \mathrm{C}\right)$ and resuspended in $10 \mathrm{ml}$ of filtered seawater before being fed to the copepods.

The food concentration (Thalassiosira weissflogii) experiment with copepods consisted of 4 treatments: $0.1,0.5,2.5,5.0 \mathrm{mg} \mathrm{l}^{-1}$. The food type experiment consisted of 4 different algal foods: T. pseudonana, Tetraselmis levis, Prorocentum minimum, and $T$. weissflogii (both in log and stationary growth phases) at a similar biomass $\left(1.0 \mathrm{mg} \mathrm{l}^{-1}\right)$. The radiolabeled phytoplankton were added to $100 \mathrm{ml}$ seawater containing 100 copepods. The initial cell density in the experimental seawater was first counted under a microscope. After 20 to $30 \mathrm{~min}$ of radioactive feeding, the copepods were immediately removed and rinsed with GF/F seawater, and then placed in $100 \mathrm{ml}$ seawater. The same type of food was added at the same concentration as used during the radioactive feeding period. The feces were collected at $2,4,8,12$, and $24 \mathrm{~h}$, during the depuration period. The water was renewed at each time point with the addition of a new batch of food particles. By the end of depuration period, all the copepods in each beaker were collected into a $5 \mathrm{ml}$ vial. The copepods and feces were solubilized with the addition of $200 \mu \mathrm{l}$ Solvable, and the radioactivity was counted after the cocktail was added. The retention of $\mathrm{BaP}$ in the animals was determined by the mass balance method, and the total amount of initial radioactivity ingested was calculated as the radioactivity retained in the copepods after the depuration $(24 \mathrm{~h})$ and the cumulative radioactivity in the feces collected during the depuration period. The $A E$ was operationally calculated as the percentage of $\mathrm{BaP}$ retained in the copepods after $12 \mathrm{~h}$ of depuration (i.e. the radioactivity in copepods at $12 \mathrm{~h}$ divided by the initial radioactivity ingested). The copepods complete their food digestion within this period of time (Wang \& Fisher 1998). In this study, we used the assimilation efficiency instead of the absorption efficiency since we calculated the $A E$ as \% of $\mathrm{BaP}$ retained in the animals, which already excluded the excretion term. The absorption efficiency is the fraction of digestive products taken up across the cell membranes of the gut wall, whereas the assimilation efficiency is the fraction of absorbed products that is incorporated into the body tissues (by excluding the excretion term; Penry 1998).

The $A E \mathrm{~s}$ of $\mathrm{BaP}$ were also measured in fish feeding at different densities of copepod prey. The copepods were radiolabeled by feeding on the radiolabeled Thalassiosira weissflogii for $12 \mathrm{~h}$, and were then fed to the snappers for $60 \mathrm{~min}$ at 4 different densities $(2,5,10$, and $20 \mathrm{mg} \mathrm{l}^{-1}$ ). After the radioactive feeding, the fish were removed and placed in nonradioactive seawater and allowed to depurate of their ingested food materials for $24 \mathrm{~h}$. During the depuration period, the snappers were fed with copepods at the same density as that used during the radioactive feeding period, and the seawater was changed every $12 \mathrm{~h}$. Feces were removed at $4,7,9,19$, and $24 \mathrm{~h}$ of the depuration. There were 8 replicates in each treatment. Similarly, the retention of $\mathrm{BaP}$ in the fish was determined by the mass balance method, as described for copepods above. Since digestion of food materials was completed within $24 \mathrm{~h}$ (e.g. very little radioactivity was detected after this period of depuration), the $A E$ was was calculated as the radioactivity retained in fish at $24 \mathrm{~h}$ divided by the initial radioactivity ingested.

Elimination of BaP from the copepods. Copepods were exposed to the radiolabeled $\mathrm{BaP}$ either in the aqueous phase or in the dietary phase. In the aqueous exposure treatment, 3000 copepods were exposed to $5 \mu \mathrm{Ci}$ of ${ }^{3} \mathrm{H}-\mathrm{BaP}\left(8.9 \mathrm{ng} \mathrm{l}^{-1}\right)$ for $12 \mathrm{~h}$. In the food exposure treatment, 3000 copepods were fed radiolabeled 
Thalassiosira weissflogii $(2 \mu \mathrm{Ci}$ in $100 \mathrm{ml}$ seawater for $\left.2 \mathrm{~h}, 104 \mathrm{ng} \mathrm{l}^{-1}\right)$ at 4 food concentrations $(0.1,0.5,2.5$, $5.0 \mathrm{mg} \mathrm{l}^{-1}$ ). After $12 \mathrm{~h}$ of radioactive feeding, the copepods were collected and rinsed with FSW, and then transferred to twelve $300 \mathrm{ml}$ glass beakers ( 3 replicates $\times 4$ food concentrations). Each beaker contained 250 copepods. At the beginning of depuration, 20 copepods were collected from each beaker to measure the initial radioactivity in the copepods. During the course of depuration, 20 copepods were collected at 2, 4, 8, $12,24,36$, and $48 \mathrm{~h}$. The seawater was renewed at 2 to $4 \mathrm{~h}$ intervals within the first $12 \mathrm{~h}$, and then every 6 to $12 \mathrm{~h}$ afterwards. The food concentrations were maintained at $0.1,0.5,2.5,5.0 \mathrm{mg} \mathrm{l}^{-1}$ during the course of the depuration period. The elimination rate constant was calculated based on the regression between the natural log of the percentage of $\mathrm{BaP}$ retained in the copepods and the time of depuration (12 to $48 \mathrm{~h}$ ).

Modeling BaP exposure. With uptake from both the aqueous and food phases and assuming that both uptake pathways are additive, the bioaccumulation of $\mathrm{BaP}$ in the animals can be described by the following equation (Landrum et al. 1992):

$$
\mathrm{d} C / \mathrm{d} t=\left(\mathrm{k}_{\mathrm{u}} \times C_{W}\right)+\left(A E \times I R \times C_{f}\right)-\left(\mathrm{k}_{\mathrm{e}} \times C\right)
$$

where $C$ is the BaP concentration in the animals at time $t, \mathrm{k}_{\mathrm{u}}$ is the uptake rate constant from the aqueous phase $\left(\mathrm{ml} \mathrm{mg}^{-1} \mathrm{~d}^{-1}\right), C_{W}$ is the BaP concentration in the aqueous phase $\left(\mu \mathrm{g} \mathrm{l}^{-1}\right), A E$ is the $\mathrm{BaP}$ assimilation efficiency, $I R$ is the ingestion rate $\left(\mathrm{mg} \mathrm{g}^{-1} \mathrm{~d}^{-1}\right), C_{f}$ is the $\mathrm{BaP}$ concentration in ingested food particles ( $\mu \mathrm{g} \mathrm{mg}^{-1}$ ) and can be measured as the BaP bioconcentration factor $(B C F$, defined as the concentration in food particles to concentration in ambient water under equilibrium conditions) in ingested food $\times C_{w}$, and $\mathrm{k}_{\mathrm{e}}$ is the BaP elimination rate constant $\left(\mathrm{d}^{-1}\right)$. The $\mathrm{k}_{\mathrm{e}}$ should include all the loss terms for the animals, including any biotransformation with the assumption that the water-soluble metabolites are excreted out of the body. With this equation, the fraction of BaP accumulated from the dissolved phase $(R)$ and the food chain transfer factor TTF under steady-state conditions can be calculated as (Wang \& Fisher 1999, Wang 2002):

$$
\begin{gathered}
R=\left(\mathrm{k}_{\mathrm{u}}\right) /\left(\mathrm{k}_{\mathrm{u}}+A E \times I R \times B C F\right) \\
T T F=(A E \times I R) / \mathrm{k}_{\mathrm{e}}
\end{gathered}
$$

\section{RESULTS}

\section{Kinetic uptake of BaP from the aqueous phase}

Fig. 1 shows the kinetic uptake of BaP by different algal species at the same biomass of $1 \mathrm{mg} \mathrm{l}^{-1}$. BaP exhibited an approximately linear pattern of uptake

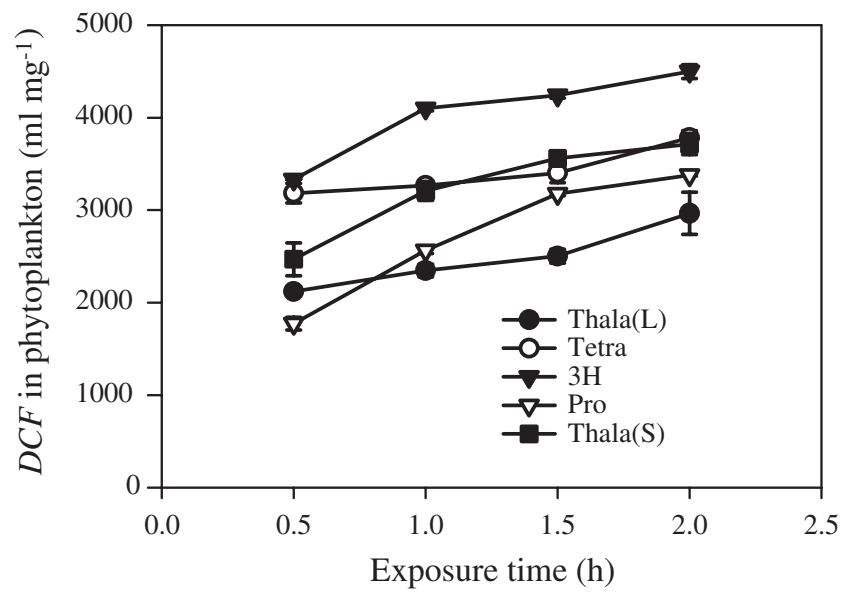

Fig. 1. Uptake of benzo(a)pyrene (BaP) by different species of phytoplankton from the aqueous phase. Uptake was quantified as the dry weight concentration factor $(D C F)$. Thala(L): Thalassiosira weissflogii in log phase, Tetra: Tetraselmis levis, 3H: T. pseudonana, Pro: Prorocentum minimum, Thala(S): T. weissflogii in stationary phase. Values are mean $\pm \mathrm{SD}, \mathrm{n}=3$

between 0.5 and $2 \mathrm{~h}$ of exposure, during which period no steady-state or equilibrium was reached. There was also an initial rapid sorption onto the algae. Given the linear pattern of uptake during the second phase, $\mathrm{k}_{\mathrm{u}}$ was calculated from the slope of the linear regression between the DCF and the time of exposure ( 0.5 to $2 \mathrm{~h}$ ), by excluding the initial sorption of BaP onto the cells (Table 1). Within the same diatom species (Thalassiosira weissflogii), the $\mathrm{k}_{\mathrm{u}}$ was significantly higher for cells in the stationary phase than for those in the log phase ( $\mathrm{p}<0.05, t$-test). The $\mathrm{k}_{\mathrm{u}}$ differed by 2.8 -fold and was the highest for the dinoflagellate Prorocentum minimum.

The kinetic uptake of BaP by the marine copepods also exhibited a linear pattern over the 1 to $8 \mathrm{~h}$ exposure period (Fig. 2). Similarly, the $\mathrm{k}_{\mathrm{u}}$ was calculated from the slope of the linear regression between the $D C F$ and the time of exposure (1 to $8 \mathrm{~h}$ ) by excluding the initial sorption of BaP. The $\mathrm{k}_{\mathrm{u}}$ was $>300$-fold lower than in phytoplankton (Table 1 ). The $\mathrm{k}_{\mathrm{u}}$ calculation assumed that there was negligible elimination of $\mathrm{BaP}$ from the copepods during the exposure period as compared to the uptake.

Aqueous uptake of BaP by the mangrove snappers was quantified both for the whole fish and different parts of the fish. A linear increase in $D C F$ with increasing exposure time (1 to $4 \mathrm{~h}$ ) was found (Fig. 3). The calculated DCF was highest for the viscera, and was comparable between the whole fish and the remaining tissues. Over the course of exposure, there were notable differences in the relative distribution of $\mathrm{BaP}$ in different fish bodies. Almost equal distribution was found for the viscera and remaining tissues, but after $4 \mathrm{~h}$ of exposure, 
Table 1. Uptake rate constant $\left(\mathrm{k}_{\mathrm{u}}\right)$ of benzo(a)pyrene (BaP) in phytoplankton, marine copepods Acartia erythraea, and mangrove snapper Lutjanus argentimaculatus. Data are mean $\pm \mathrm{SD}, \mathrm{n}=3$

\begin{tabular}{|lc|}
\hline Species & $\mathrm{k}_{\mathrm{u}}\left(\mathrm{ml} \mathrm{mg}^{-1} \mathrm{~h}^{-1}\right)$ \\
\hline Phytoplankton & \\
Thalassiosira weissflogii (log phase) & $540 \pm 92$ \\
Thalassiosira weissflogii (stationary) & $818 \pm 188$ \\
Tetraselmis levis & $387 \pm 97$ \\
Prorocentum minimum & $1086 \pm 190$ \\
Thalassiosira pseudonana & $728 \pm 193$ \\
Copepods & $1.20 \pm 0.20$ \\
Mangrove snappers & \\
Gill & $0.314 \pm 0.040$ \\
Viscera & $1.114 \pm 0.081$ \\
Remaining tissue & $0.011 \pm 0.002$ \\
Whole body & $0.157 \pm 0.042$ \\
\hline
\end{tabular}

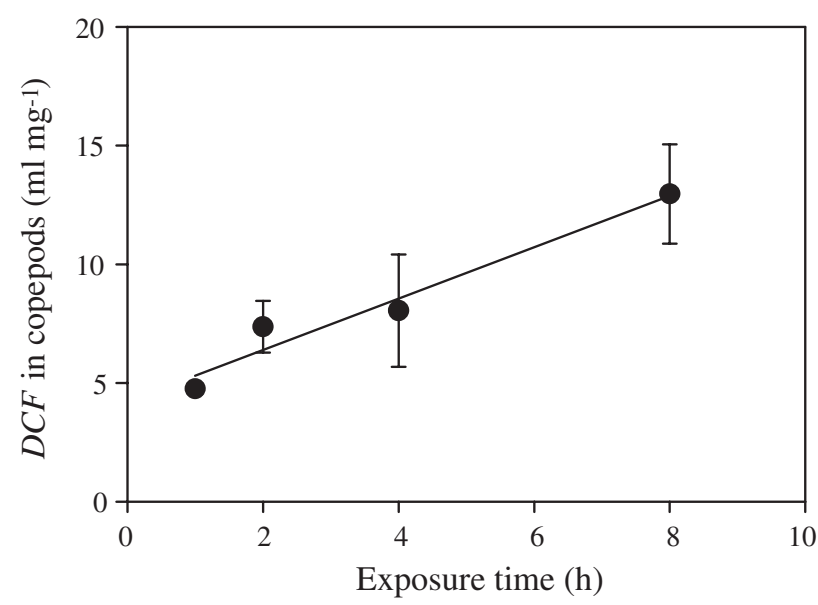

Fig. 2. Acartia erythraea. Uptake of BaP by the copepods from the aqueous phase. Uptake was quantified as the dry weight concentration factor $(D C F)$. Values are mean $\pm \mathrm{SD}, \mathrm{n}=3$

the fraction distributed in the viscera increased. The $\mathrm{k}_{\mathrm{u}}$ in the whole fish and different body parts was also calculated from the slope of the linear regression between the $D C F$ and the time of exposure (1 to $4 \mathrm{~h}$ ) by excluding the initial sorption of BaP (Table 1). The highest $k_{\mathrm{u}}$ was found for the viscera, whereas the remaining tissues had the lowest $\mathrm{k}_{\mathrm{u}}$. For the whole fish, the $\mathrm{k}_{\mathrm{u}}$ was 7.6 times lower than the $\mathrm{k}_{\mathrm{u}}$ of copepods.

\section{Assimilation of BaP by copepods and fish}

Generally, rapid egestion of unassimilated BaP by copepods was found within the first few hours of depuration (Fig. 4). At a higher food concentration, the depuration by the copepods was much faster. After the initial rapid loss, BaP was then depurated from the copepods at a slower rate. The calculated AEs
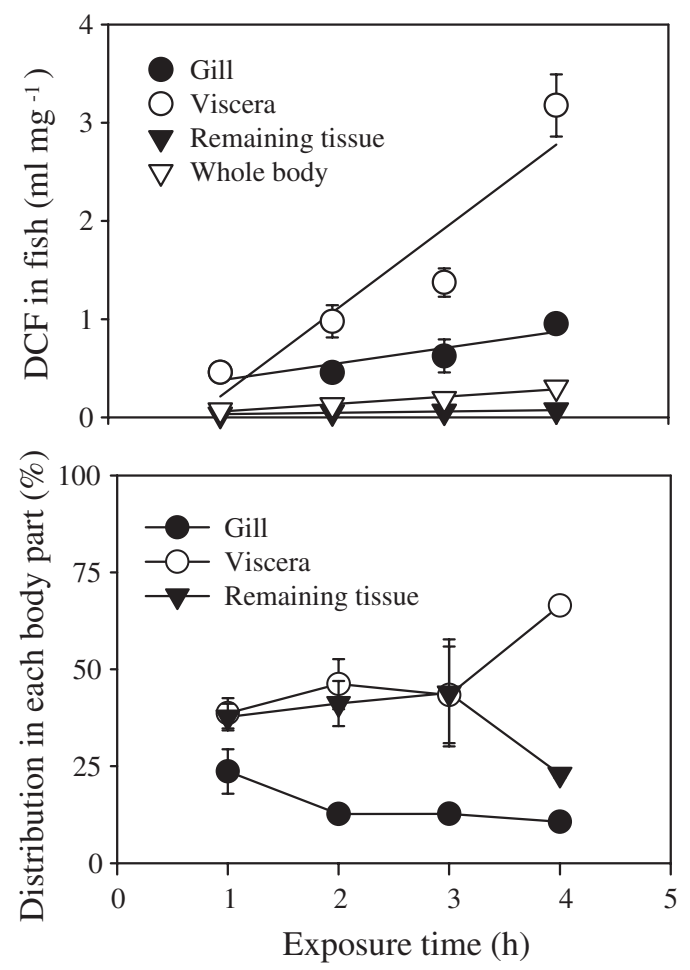

Fig. 3. Lutjanus argentimaculatus. Uptake of BaP from the aqueous phase, and the distribution in different tissues over exposure period. The uptake was quantified as the dry weight concentration factor $(D C F)$. Values are mean $\pm \mathrm{SD}, \mathrm{n}=3$

decreased significantly with increasing food concentrations ( $p<0.001$, Table 2 ). The greatest change in $A E$ occurred at the food concentration between 0.1 to 0.5 $\mathrm{mg} \mathrm{l}^{-1}$. The AEs decreased by $13.6 \times$ with increasing food concentrations from 0.1 to $5.0 \mathrm{mg} \mathrm{l}^{-1}$. Depuration of $\mathrm{BaP}$ in copepods feeding on different algal types followed similar patterns (Fig. 4). The tested algal biomass in this experiment was relatively high $\left(1 \mathrm{mg} \mathrm{l}^{-1}\right)$, thus the calculated $A E$ s were rather low (3 to $9 \%$ ), and the differences among different algal diets were small. For the same diatom diet (Thalassiosira weissflogii), the $A E$ s were $5.6 \%$ for the stationary cells as compared to $2.9 \%$ for the log growing cells.

The depuration of ingested $\mathrm{BaP}$ in the mangrove snappers feeding at different copepod prey densities is shown in Fig. 5. The $A E$ decreased significantly with increasing copepod density ( $\mathrm{p}<0.05$, Table 2 ). For example, the $A E$ varied by 1.6 -fold over the copepod density of 2 to $20 \mathrm{mg} \mathrm{l}^{-1}$. The calculated AEs were much higher than those measured for the marine copepods.

\section{BaP elimination from copepods}

The copepods were exposed to radiolabeled water or diatom food for $12 \mathrm{~h}$ and their retention was followed 
for $2 \mathrm{~d}$ at different diatom food concentrations (Fig. 6). By the end of the depuration, the \% of BaP that remained in the copepods was similar for the aqueous and dietary exposure. For the aqueous exposure

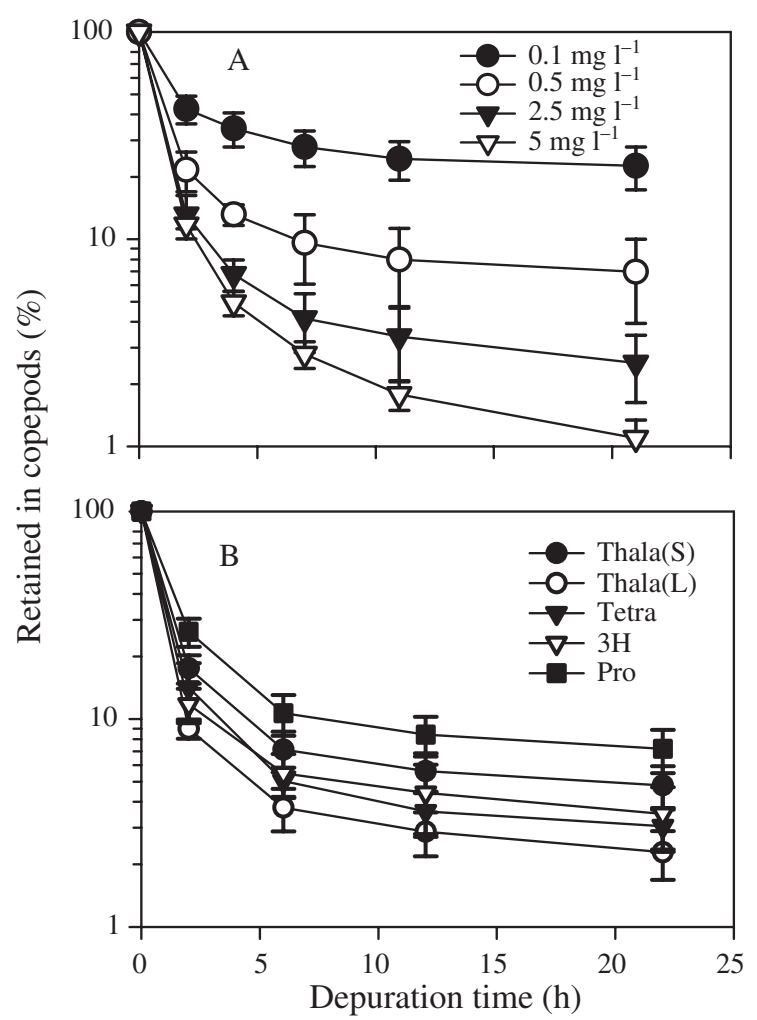

Fig. 4. Acartia erythraea. Retention of BaP by the copepods following a pulse ingestion of radiolabeled diatom Thalassiosira weissflogii (A) at different cell densities or (B) following pulse ingestion of different radiolabeled phytoplankton. Values are mean $\pm \mathrm{SD}, \mathrm{n}=3$. Thala(S): T. weissflogii in stationary phase, Thala(L): $T$. weissflogii in log phase, Tetra: Tetraselmis levis, 3H: T. pseudonana, Pro: Prorocentum minimum

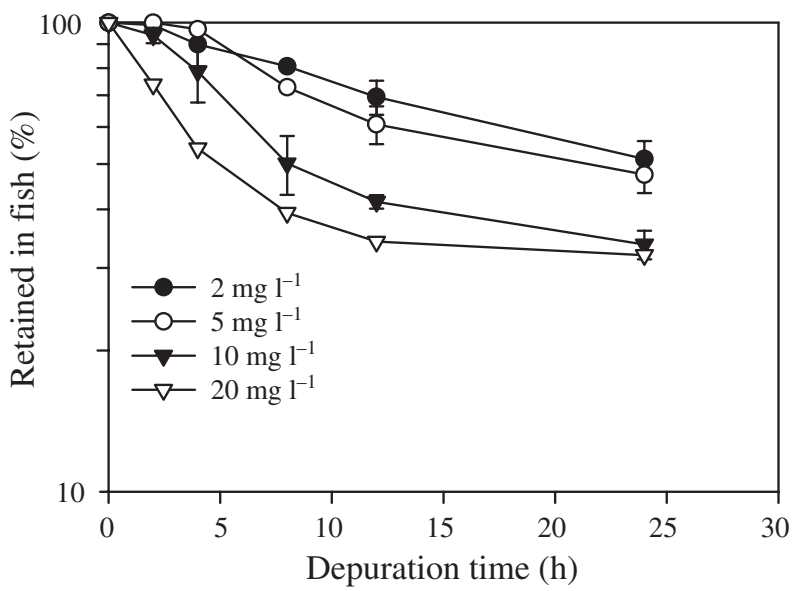

Fig. 5. Lutjanus argentimaculatus. Retention of BaP following a pulse ingestion of radiolabeled copepods (Acartia erythraea) at different prey densities. Values are mean $\pm S D, n=8$ experiment, the BaP was retained at a higher efficiency at lower food concentrations. The elimination rate constant $\left(\mathrm{k}_{\mathrm{e}}\right)$ was similar for the aqueous and dietary exposure (Table 3). Differences in food concentrations did not significantly affect the BaP elimination from the copepods ( $p>0.05,1$-way ANOVA).

\section{Modeling BaP exposure in copepod and fish}

Eq. (2) was used to calculate the relative exposure (aqueous vs. food) of BaP in the copepods and fish. Values of $\mathrm{k}_{\mathrm{u}}$ and $A E$ were derived from this study, and the ingestion rates of copepods and fish were obtained from the literature (Table 4). The BCFs in phytoplankton were selected based on our short-term measurement of BaP uptake. However, we assume that the $B C F$ varies by one order of magnitude $\left(10^{6}\right.$ to $\left.10^{7} 1 \mathrm{~kg}^{-1}\right)$

Table 2. Assimilation efficiency $(A E)$ of BaP by marine copepods (Acartia erythraea) and mangrove snappers (Lutjanus argentimaculatus) under different food conditions. Significant influence of food concentration on $A E$ is indicated by ${ }^{*}(p<$ $0.05)$ and ${ }^{* * *}(p<0.001,1$-way ANOVA). Data are mean $\pm \mathrm{SD}, \mathrm{n}=3$ for copepods and 8 for fish

\begin{tabular}{|c|c|}
\hline Treatments & $A E(\%)$ \\
\hline \multicolumn{2}{|l|}{ Copepods } \\
\hline \multicolumn{2}{|c|}{ Food concentration $\left(\mathrm{mg} \mathrm{l}^{-1}\right.$ Thalassiosira weissflogii) $\left({ }^{* * *}\right)$} \\
\hline 0.1 & $24.4 \pm 5.2$ \\
\hline 0.5 & $7.9 \pm 3.3$ \\
\hline 2.5 & $3.4 \pm 1.4$ \\
\hline 5.0 & $1.8 \pm 0.3$ \\
\hline \multicolumn{2}{|l|}{ Food type $\left(1 \mathrm{mg} \mathrm{l}^{-1}\right)$} \\
\hline Thalassiosira weissflogii (log phase) & $2.9 \pm 0.7$ \\
\hline Thalassiosira weissflogii (stationary) & $5.6 \pm 1.2$ \\
\hline Tetraselmis levis & $3.6 \pm 0.9$ \\
\hline Prorocentum minimum & $8.4 \pm 1.8$ \\
\hline Thalassiosira pseudonana & $4.4 \pm 1.6$ \\
\hline \multicolumn{2}{|l|}{ Mangrove snappers } \\
\hline \multicolumn{2}{|l|}{ Copepod prey concentration $\left(\mathrm{mg} \mathrm{l}^{-1}\right)\left({ }^{*}\right)$} \\
\hline 2 & $51.2 \pm 4.7$ \\
\hline 5 & $47.4 \pm 4.1$ \\
\hline 10 & $33.6 \pm 2.4$ \\
\hline 20 & $31.9 \pm 1.6$ \\
\hline
\end{tabular}

Table 3. Acartia erythraea. Elimination rate constants $\left(\mathrm{k}_{\mathrm{e}}\right)$ of $\mathrm{BaP}$ after aqueous and dietary exposure (mean $\pm \mathrm{SD}, \mathrm{n}=3$ )

\begin{tabular}{|lcr|}
\hline \multirow{2}{*}{$\begin{array}{l}\text { Diatom concentration } \\
\left(\mathrm{mg} \mathrm{l}^{-1}\right)\end{array}$} & \multicolumn{2}{c|}{$\mathrm{k}_{\mathrm{e}}\left(\mathrm{d}^{-1}\right)$} \\
\hline 0.1 & $0.82 \pm 0.10$ & $1.01 \pm 0.07$ \\
0.5 & $0.96 \pm 0.12$ & $1.01 \pm 0.10$ \\
2.5 & $1.66 \pm 0.12$ & $1.39 \pm 0.24$ \\
5.0 & $1.30 \pm 0.14$ & $1.15 \pm 0.14$ \\
\hline
\end{tabular}


given the uncertainty of this parameter (especially given the initial sorption). The $B C F$ of $\mathrm{BaP}$ in the copepods as the prey of fish was calculated as $\left(\mathrm{k}_{\mathrm{u}}+A E \times I R \times\right.$ $\left.B C F_{\text {phytoplankton }}\right) / \mathrm{k}_{\mathrm{e}}$. Using a phytoplankton BCF of $4 \times$ $10^{6} \mathrm{l} \mathrm{kg}^{-1}$ and an $A E$ of $5 \%$, the BCF in the copepods was calculated as $9 \times 10^{4} \mathrm{lkg}^{-1}$. We therefore use $5 \times 10^{4}$ to $5 \times 10^{5} 1 \mathrm{~kg}^{-1}$ as the range of copepod $B C F \mathrm{~s}$ in the fish accumulation model calculation. Thus, under the likely conditions encountered by the copepods, the uptake for BaP was variable and greatly dependent on the $A E$ (Fig. 7). Assuming an average $A E$ (5\%, Table 4), >50\% of $\mathrm{BaP}$ are derived from the food intake under most $B C F$ conditions, suggesting that trophic transfer is more important than the aqueous uptake. For the mangrove snappers, the relative importance is related to the ingestion rate of the fish and the BCF in the prey (Fig. 8). Assuming a median ingestion rate $\left(0.05 \mathrm{~g} \mathrm{~g}^{-1} \mathrm{~d}^{-1}\right.$, Zhao et al. 2001) and $A E(40 \%)$, trophic transfer contributes 21 to $72 \%$ to the total BaP accumulation in fish over the $B C F$ range simulated, implying that both aqueous uptake and dietary uptake can be equally important for the overall $\mathrm{BaP}$ accumulation in the fish.

It is also possible to calculate the trophic transfer factor (TTF) for the copepods using Eq. (3) with known $A E, I R$, and $\mathrm{k}_{\mathrm{e}}$. The TTF in the copepods fed with phytoplankton is consistently $<0.1$ under all conditions, thus the potential for trophic transfer of BaP from phytoplankton to copepods is very low.

\section{DISCUSSION}

Fan \& Reinfelder (2003) indicated that the sorption of phenanthrene occurred within the first $20 \mathrm{~min}$ of contact with the diatoms, followed by passive diffu-

Table 4. Parameters used in modeling the exposure of BaP in the marine copepod Acartia erythraea and the mangrove snapper Lutjanus argentimaculatus. IR: ingestion rate, $\mathrm{k}_{\mathrm{u}}$ : dissolved uptake rate constant, $A E$ : assimilation efficiency, $\mathrm{k}_{\mathrm{e}}$ : elimination rate constant, $B C F$ : bioconcentration factor in prey

\begin{tabular}{|lccl|}
\hline & Range & Mean & Source \\
\hline Copepods & & & \\
$I R\left(\mathrm{~g} \mathrm{~g}^{-1} \mathrm{~d}^{-1}\right)$ & $0.2-0.6$ & 0.4 & Wang \& Fisher (1998) \\
$\mathrm{k}_{\mathrm{u}}\left(\mathrm{l} \mathrm{g}^{-1} \mathrm{~h}^{-1}\right)$ & & 1.2 & This study \\
$A E(\%)$ & $2-25$ & 5 & This study \\
$\mathrm{k}_{\mathrm{e}}\left(\mathrm{d}^{-1}\right)$ & $0.82-1.66$ & 1.20 & This study \\
$B C F\left(\mathrm{~kg}^{-1}\right)$ & $10^{6}-10^{7}$ & & This study \\
Mangrove snappers & & \\
$I R\left(\mathrm{~g} \mathrm{~g}^{-1} \mathrm{~d}^{-1}\right)$ & $0.01-0.1$ & 0.05 & Zhao et al. (2001) \\
$\mathrm{k}_{\mathrm{u}}\left(\mathrm{l} \mathrm{g}^{-1} \mathrm{~h}^{-1}\right)$ & & 0.157 & This study \\
$A E(\%)$ & $30-50$ & 40 & This study \\
$B C F\left(\mathrm{~kg}^{-1}\right)$ & $5 \times 10^{4}-5 \times 10^{5}$ & This study \\
\hline
\end{tabular}

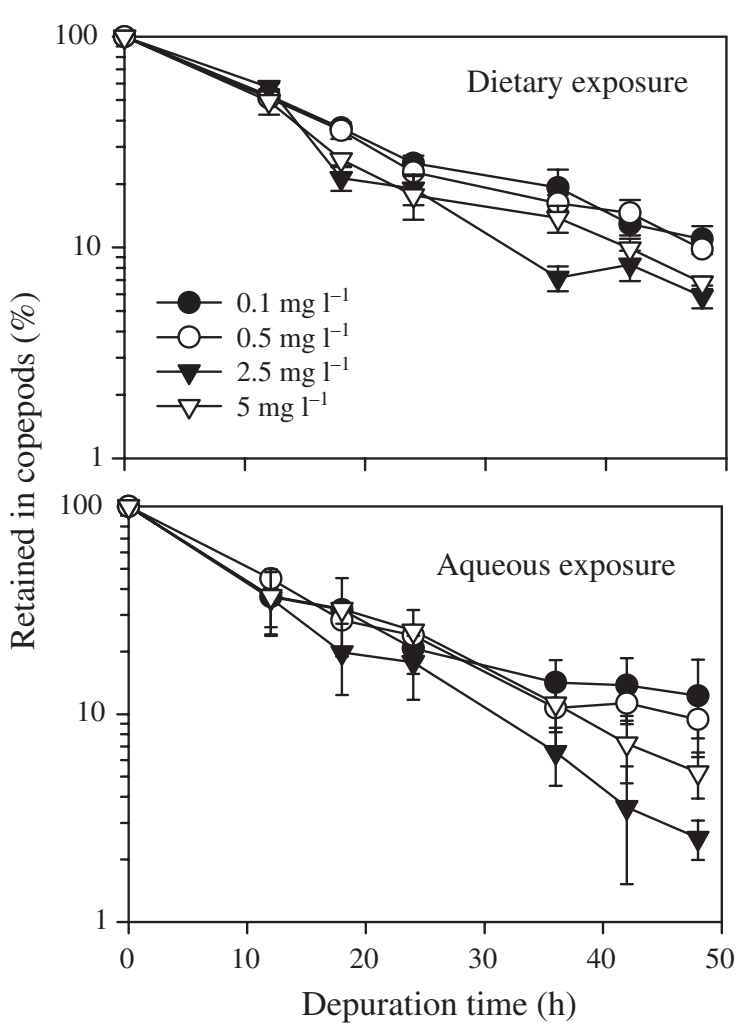

Fig. 6. Acartia erythraea. Retention of BaP following dietary or aqueous exposure for $12 \mathrm{~h}$, at different diatom densities. Values are mean $\pm \mathrm{SD}, \mathrm{n}=3$

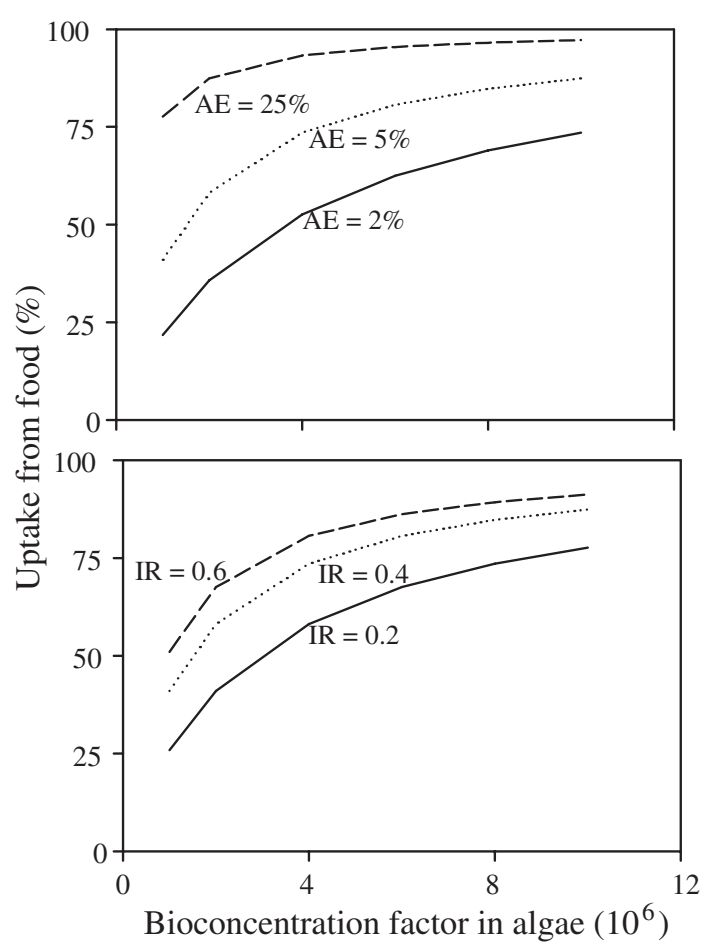

Fig. 7. Acartia erythraea. Predicted percentage of BaP uptake from the dietary phase in marine copepods as a function of $\mathrm{BaP}$ bioconcentration factor in phytoplankton. $A E$ : assimilation efficiency from food, $I R$ : ingestion rate of copepods $\left(\mathrm{g} \mathrm{g}^{-1} \mathrm{~d}^{-1}\right)$ 


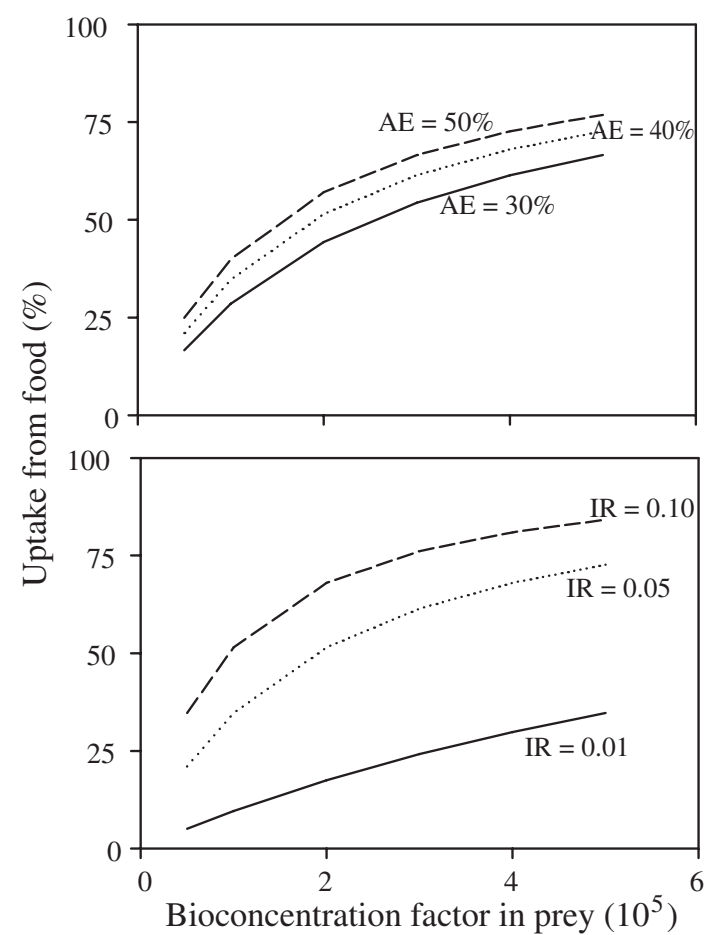

Fig. 8. Lutjanus argentimaculatus. Predicted percentage of $\mathrm{BaP}$ uptake from the dietary phase as a function of BaP bioconcentration factor in prey. AE: assimilation efficiency from food, $I R$ : ingestion rate of the fish $\left(\mathrm{g} \mathrm{g}^{-1} \mathrm{~d}^{-1}\right)$

sion into the cells with increasing exposure. Lei et al. (2002) examined the uptake of pyrene by several algae and found that $>65 \%$ of pyrene was adsorbed onto the cell walls of Selenastrum capricornutum, suggesting that the major binding sites for these $\mathrm{PAH}$ compounds were on the cell surfaces. In our study, we also found that the initial sorption dominated the overall accumulation of $\mathrm{BaP}$ by the organisms. Because of the passive physico-chemical biosorption, the specific surface area may critically influence the sorption of BaP by the phytoplankton. At the beginning of exposure, the quantified concentration factors were generally the highest for the diatom Thalassiosira pseudonana, which may be attributed to their small size ( 3 to $5 \mu \mathrm{m}$ ) and large surface area to volume ratio. By excluding the initial sorption, we calculated the uptake rate constant based on the linear regression between the second phase of accumulation and the time of exposure. The internal accumulation of hydrophobic organic contaminants, especially those with $\mathrm{K}_{\mathrm{ow}}>6$, by phytoplankton can be very slow (Swackhamer \& Skoglund 1993, Stange \& Swackhamer 1994, Jabusch \& Swackhamer 2004). Thus, the short-term exposures of phytoplankton to dissolved PAHs may not have fully labelled internal compartments and may result in the overestimation of accu- mulation rates (which reflect mainly surface accumulation). The phytoplankton BaP uptake rates reported in Table 1 are indeed an order of magnitude higher than those predicted $\left(64 \mathrm{ml} \mathrm{mg}^{-1} \mathrm{~h}^{-1}\right)$ for the intracellular accumulation of the most hydrophobic PAHs, including $\mathrm{BaP}$, for a similarly sized cell (Del Vento \& Dachs 2002).

The DCF of BaP in copepods was lower than that in phytoplankton, again probably due to their lower surface area to volume ratios. The lipid composition in marine copepods varied from 4 to $43 \%$ of the dry weight (Buhring \& Christiansen 2001, Fisk et al. 2001), and was comparable to or higher than those in marine phytoplankton (5 to $6 \%$, Wahbeh 1997). Given the much higher $D C F$ for phytoplankton than for copepods, the biosorption was presumably much more important in determining the $\mathrm{BaP}$ uptake than the lipid content. Among the different tissues of fish, the accumulation was the highest for the viscera, most likely due to the highest lipid content and the rapid transport to this tissue. Spacie et al. (1983) found that the uptake of BaP by the bluegill sunfish was linear, although the biotransformation increased between 1 and $2 \mathrm{~h}$ of exposure. At $4 \mathrm{~h}$, only $11 \%$ of the ${ }^{14} \mathrm{C}$ activity represented the parent compound and $25 \%$ of the BaP was distributed into the liver and gall bladder (Spacie et al. 1983).

The $A E$ s by copepods varied over the range of 2 to $24 \%$ within the food concentration range tested $(0.1$ to $5.0 \mathrm{mg} \mathrm{l}^{-1}$ ). Our study demonstrated that the AEs of $\mathrm{BaP}$ were dependent on the food quantity, and were generally very low at a high food concentration. Because the $A E$ s for different algal foods were quantified at a high food concentration $\left(1.0 \mathrm{mg} \mathrm{l}^{-1}\right)$, they were too low to result in a meaningful comparison among the different algae. In earlier experimental studies, it was found that the marine copepods typically had a low retention of PAHs. For example, the copepods lost $>35 \%$ of naphthalene accumulated from the food over the $24 \mathrm{~h}$ depuration period (Corner et al. 1976, Harris et al. $1977 \mathrm{a}, \mathrm{b})$. Furthermore, the slow intracellular accumulation of BaP by phytoplankton may affect the interpretation of the $A E$ experiments in which phytoplankton were labeled for $2 \mathrm{~h}$ before fed to copepods. It is possible that the low BaP AEs measured in copepods may have resulted from the insufficient labeling of intracellular compartments in the phytoplankton.

The measured AEs of BaP (30 to $50 \%$ ) for the mangrove snappers were higher than those determined for the marine copepods. For fish, enzymes responsible for biotransformation included Phase I cytochrome P450 monooxygenase or MFO system. Livingstone (1998) found that fish metabolized $\mathrm{BaP}$ at a faster rate than the other animals, consistent with the higher levels of 
total cytochrome P450 and inducible cytochrome P4501A (CYP1A) activity. Given the higher P450 activity in the fish and the higher $A E$ as compared to the copepods, biotransformation was not the only factor affecting the retention of these PAH compounds in the animals. Digestive physiology may also play an important role in the assimilation of these dietary PAH chemicals. In contrast, previous studies found that the $A E \mathrm{~s}$ of the PAH compounds in fish measured using similar methodology were relatively low $(<15 \%$ for naphthalene and BaP; Corner et al. 1976, Fair \& Fortner 1987, Lemaire et al. 1992).

In our radiolabeling of phytoplankton used for the $A E$ measurements, we used a rather short exposure period $(2 \mathrm{~h})$ and it was assumed that the biotransformation was negligible over the relatively short period. Similarly, the copepods were radiolabeled with BaP for $12 \mathrm{~h}$ before they were fed to the fish. It was also assumed that biotransformation was minor within this period, but this would require further experimental confirmation. We calculated the $A E$ by fish after $24 \mathrm{~h}$ of depuration and assumed that the hydroxyl metabolism can be ignored during the second phase of depuration. A recent study demonstrated that a significantly higher liver EROD activity was only detected after the fish (Acanthopagrus schlegeli) were exposed to $1.0 \mu \mathrm{g} \mathrm{l}^{-1}$ of $\mathrm{BaP}$ for $2 \mathrm{~d}$ (Wang, in press), suggesting that biotransformation was not significant within the first $2 \mathrm{~d}$ (within our $A E$ measurement period). Since the $A E$ was calculated after $24 \mathrm{~h}$, the biotransformed products (if any) may have been excreted, and the effects on $A E$ calculation may be reduced. However, further experimental studies are required to assess the implication of biotransformation on the biokinetics of $\mathrm{BaP}$ in aquatic animals.

The high elimination rate constants $\left(0.8\right.$ to $\left.1.7 \mathrm{~d}^{-1}\right)$ of BaP in copepods were presumably related to their rapid metabolism and the small body sizes of the animals. In examining the physiological efflux of metals, it has also been shown that the marine copepods (Acartia spinicauda) were able to eliminate the metals rapidly (at rates similar to those found for $\mathrm{BaP}$ in this study) as a result of their small body sizes (Xu et al. 2001). Landrum et al. (2003) reported that the $\mathrm{k}_{\mathrm{e}}$ in freshwater amphipods, Diporeia spp., was 0.12 to $0.55 \mathrm{~d}^{-1}$ for naphthalene, 0.12 to $0.22 \mathrm{~d}^{-1}$ for phenanthrene, and 0.05 to $0.07 \mathrm{~d}^{-1}$ for pyrene, respectively. These rate constants were much lower than the $\mathrm{k}_{\mathrm{e}}$ of $\mathrm{BaP}$ in copepods measured in this study. Lotufo (1998) quantified the depuration of fluoranthene with 4 benzene rings $\left(\log \mathrm{K}_{\mathrm{ow}}=5.23\right)$ in 2 copepod species (Schizopern knabeni and Coullana sp). The biological retention half life of this compound were 4.8 to $7.4 \mathrm{~h}$ (with a corresponding elimination rate constant of 2.2 to $3.4 \mathrm{~d}^{-1}$ ), again illustrating that the freshwater zooplankton had an efficient elimination system to remove or metabolize the PAH compounds.

With the use of a simple kinetic model, we found that the BaP uptake by copepods was dominated by food uptake instead of dissolved exposure. Dietary accumulation plays an important role under most conditions simulated in this study. The significance of trophic transfer was principally due to the very high $B C F$ of phytoplankton diets, despite the fact that the $A E$ was low and the $\mathrm{k}_{\mathrm{u}}$ was high. For the mangrove snappers, dietary intake also plays an important role under conditions likely encountered by the fish, but it depends greatly on the feeding rate of the fish as well as the concentration of BaP in the copepod prey. It has been considered that uptake via food rather than dissolved phase is the dominant exposure route for compounds with $\log \mathrm{K}_{\mathrm{ow}}>5$ (Thomann 1989, Connolly \& Pedersen 1988). Dietary exposure is, however, not taken into consideration in the laboratory studies because of the technical difficulty in creating a realistic dietary exposure regime, even though some studies have shown the dominance of dietary exposure for poorly watersoluble compounds such as PCBs (Randall et al. 1998). Laboratory studies with rainbow trout, however, did not reveal significant accumulation through dietary exposure, apparently as a result of their poor assimilation efficiency from the diets and the rapid elimination of PAHs (Niimi \& Dookhran 1989). Overall, our modeling results imply that trophic transfer should be considered in examining the bioaccumulation of $\mathrm{BaP}$ in marine animals and that the relative importance of trophic transfer is dependent on various biological and environmental conditions.

Our calculations of the trophic transfer factor (TTF) with typically $<0.1$ are consistent with many field observations that $\mathrm{PAH}$ is not biomagnified in the marine zooplankton (Fisk et al. 2001). Fisk et al. (2001) demonstrated that the concentrations of hydrophobic persistent organic pollutants ( $\log \mathrm{K}_{\mathrm{ow}}=3.8$ to 6.0 ) in zooplankton are likely to reflect water concentrations and that these compounds do not biomagnify in zooplankton. One main mechanism for the low TTF was the biotransformation of $\mathrm{BaP}$, which may metabolize a fraction of the absorbed $\mathrm{BaP}$ to polar metabolites or phenolic compounds, resulting in a rapid elimination of these compounds by the marine copepods. Measurements of the biokinetics of PAH compounds can thus aid in understanding the trophic interactions of PAHs in marine food chains.

Acknowledgements. We acknowledge the critical comments by the anonymous reviewers. This study was supported by the Areas of Excellence Scheme established under the University Grants Committee of the Hong Kong SAR (Project No. AoE/P-04/2004). 


\section{LITERATURE CITED}

Barron MG (1990) Bioconcentration. Environ Sci Technol 24: 1612-1618

Buhring SI, Christiansen B (2001) Lipids in selected abyssal bentho-pelagic animals: links to the epipelagic zone? Prog Oceanogr 50:369-382

Connell DW, Wu RSS, Richardson BJ, Leung K, Lam PSK, Connell PA (1998) Occurrence of persistent organic contaminants and related substances in Hong Kong marine areas: an overview. Mar Pollut Bull 36:376-384

Connolly JP, Pedersen CJ (1988) A thermodynamic-based evaluation of organic chemical accumulation in aquatic organisms. Environ Sci Technol 22:99-103

Corner EDS, Harris RP, Kilvington CC, O'Hara SCM (1976) Petroleum compounds in the marine food web: short-term experiments on the fate of naphthalene in Calanus. J Mar Biol Assoc UK 56:121-133

D'Adamo R, Pelosi S, Trotta P, Sasone G (1997) Bioaccumulation and biomagnification of polycyclic aromatic hydrocarbons in aquatic organisms. Mar Chem 56:45-49

Del Vento S, Dachs J (2002) Prediction of uptake dynamics of persistent organic pollutants by bacteria and phytoplankton. Environ Toxicol Chem 21:2099-2107

Fair PH, Fortner AR (1987) Effect of ingested benzo(a)pyrene and cadmium on tissue accumulation, hydroxylase activity, and intestinal morphology of the black sea bass, Centropristis striata. Environ Res 42:185-195

Fan CW, Reinfelder JR (2003) Phenanthrene accumulation kinetics in marine diatoms. Environ Sci Technol 37: 3405-3412

Fisk AT, Stern GA, Hobson KA, Strachan WJ (2001) Persistent organic pollutants (POPs) in a small herbivorous, Arctic marine zooplankton (Calanus hyperboreus): trends from April to July and the influence of lipids and trophic transfer. Mar Pollut Bull 43:93-101

Guillard RRL, Ryther JH (1962) Studies on marine planktonic diatoms. I. Cyclotella nana hustedt and Detonula confervacea (Cleve) Gran. Can J Microbiol 8:229-239

Harris RP, Berdugo V, O'Hara SCM, Corner EDS (1977a) Accumulation of ${ }^{14} \mathrm{C}$-l-naphthalene by an oceanic and an estuarine copepod during long-term exposure to low-level concentrations. Mar Biol 42:187-195

Harris RP, Berdugo V, Corner EDS, Kilvington CC, O'Hara SCM (1977b) Factors affecting the retention of a petroleum hydrocarbon by marine planktonic copepods. In: Wolfe DA (ed) Fate and effects of petroleum hydrocarbons in marine organisms and ecosystems. Pergamon, New York, p 78-94

Hellou J, Mackay D, Fowler B (1995) Bioaccumulation of polycyclic aromatic compounds from sediments to muscle of finfish. Environ Sci Technol 29:2555-2560

Jabusch TW, Swackhamer DL (2004) Subcellular accumulation of polychlorinated biphenyls in the green alga Chlamydomonas reinhardii. Environ Toxicol Chem 23:2823-2830

Kane DS, McElroy AE (1996) Bioaccumulation and metabolism of benzo(a)pyrene in three species of polychaete worms. Environ Toxicol Chem 15:1401-1410

Klosterhaus SL, Ferguson PL, Chandler GT (2002) Polycyclic aromatic hydrocarbon bioaccumulation by meiobenthic copepods inhabiting a superfund site: techniques for micromass body burden and total lipid analysis. Environ Toxicol Chem 21:2331-2337

Klumpp DW, Hong HS, Humphrey C, Wang XH, Codi S (2002) Toxic contaminants and their biological effects in coastal waters of Xiamen, China. I. Organic pollutants in mussel and fish tissues. Mar Pollut Bull 44:752-760
Landrum PF, Lee H, Lydy MJ (1992) Toxicokinetics in aquatic systems: model comparisons and use in hazard assessment. Environ Toxicol Chem 11:1709-1725

Landrum PF, Lotufo GR, Gossiaux DC, Gedeon ML, Lee JH (2003) Bioaccumulation and critical body residue of polynuclear aromatic hydrocarbons in the amphipod, Diporeia spp.: additional evidence to support toxicity additivity for PAH mixtures. Chemosphere 51:481-489

Lei AP, Wong YS, Tam NFY (2002) Removal of pyrene by different microalgal species. Water Sci Technol 46:195-201

Lemaire P, Mathieu A, Carriere S, Narbonne J-F, Lafaurie M, Giudicelli J (1992) Hepatic biotransformation enzymes in aquaculture European sea bass (Dicentrarchus labrax): kinetic parameters and induction with benzo(a)pyrene. Comp Biochem Physiol 103B:847-853

Livingstone DR (1998) The fate of organic xenobiotics in aquatic ecosystems: quantitative and qualitative differences in biotransformation by invertebrates and fish. Comp Biochem Physiol 120A:43-49

Lotufo GR (1998) Bioaccumulation of sediment-associated fluoranthene in benthic copepods: uptake, elimination and biotransformation. Aquat Toxicol 44:1-15

Maskaoui K, Zhou JL, Hong HS, Zhang ZL (2002) Contamination by polycyclic aromatic hydrocarbons in the Jiulong River Estuary and Western Xiamen Sea, China. Environ Pollut 118:109-122

Moore MR, Vetter W, Gaus C, Shaw GR, Muller JF (2002) Trace organic compounds in the marine environment. Mar Pollut Bull 45:62-68

Meador JP, Stein JE, Reichert WL, Varanasi U (1995) Bioaccumulation of polycyclic aromatic hydrocarbons by marine organisms. Rev Environ Contam Toxicol 143:79-165

Neff JM (2002) Bioaccumulation in marine organisms: effect of contaminants from oil well. Elsevier, Amsterdam

Neff JM, Burns WA (1996) Estimation of polycyclic aromatic hydrocarbon concentrations in the water column based on tissue residues in mussels and salmon: an equilibrium partitioning approach. Environ Toxicol Chem 15:2220-2254

Niimi AJ, Dookhran GP (1989) Dietary assimilation efficiencies and elimination rates of polycyclic aromatic hydrocarbons (PAHs) in rainbow trout (Oncorhynchus mykiss). Arch Environ Contam Toxicol 8:719-722

Penry DL (1998) Applications of efficiency measurements in bioaccumulation studies: definitions, clarifications, and a critique of methods. Environ Toxicol Chem 17:1633-1639

Randall DJ, Connell DW, Yang R, Wu RSS (1998) Concentrations of persistent lipophilic compounds in fish are determined by exchange across the gills, not through the food chain. Chemosphere 37:1263-1270

Spacie A, Landrum PF, Leversee GJ (1983) Uptake, depuration, and biotransformation of anthracene and benzo [a]pyrene in bluegill sunfish. Ecotoxicol Environ Saf 7: 330-41

Stange K, Swackhamer DL (1994) Factors affecting phytoplankton species-specific differences in accumulation of 40 polychlorinated-biphenyls (PCBs). Environ Toxicol Chem 13:1849-1860

Swackhamer DL, Skoglund RS (1993) Bioaccumulation of PCBs by algae-kinetics versus equilibrium. Environ Toxicol Chem 12:831-838

Thomann RV (1989) Bioaccumulation model of organic chemical distribution in aquatic food chains. Environ Sci Technol 23:699-707

van der Oost R, Heida H, Opperhuizen A, Vermeulen NPE (1991) Interrelationships between bioaccumulation of organic trace pollutants (PCBs, organochlorine pesticides and PAHs) and MFO-induction in fish. Comp Biochem 
Physiol 100C:43-47

Veith GD, Kosian P (1983) Estimating bioconcentration potential from octanol/water partition coefficients. In: Mackay D, Patterson S, Eisenreich SJ, Simmons MS (eds) Physical behavior of PCBs in the Great Lakes. Ann Arbor Science Publishers, Ann Arbor, p 269-282

Wahbeh MI (1997) Amino acid and fatty acid profiles of four species of macroalgae from Aqaba and their suitability for use in fish diets. Aquaculture 159:101-109

Wang WX (2002) Interactions of trace metals and different marine food chains. Mar Ecol Prog Ser 243:295-309

Wang WX, Fisher NS (1998) Accumulation of trace elements in a marine copepod. Limnol Oceanogr 43:273-283

Wang WX, Fisher NS (1999) Assimilation efficiencies of chemical contaminants in aquatic invertebrates: a synthesis. Environ Toxicol Chem 18:2034-2045

Editorial responsibility: Otto Kinne (Editor-in-Chief), Oldendorf/Luhe, Germany
Wang WX, Fisher NS, Luoma SN (1996) Kinetic determinations of trace element bioaccumulation in the mussel, Mytilus edulis. Mar Ecol Prog Ser 140:91-113

Wang XH (in press) Induction of EROD activity in the liver of black porgy (Acanthopagrus schlegeli) exposed to benzo[a]pyrene. Aquat Ecosystem Health Management

Xu Y, Wang WX, Hsieh DPH (2001) Influences of metal concentration in phytoplankton and seawater on metal assimilation and elimination in marine copepods. Environ Toxicol Chem 20:1067-1077

Zaroogian GE, Heltshe JF, Johnson M (1985) Estimation of bioconcentration in marine species using structureactivity relationships. Environ Toxicol Chem 4:3-12

Zhao X, Wang WX, Yu KN, Lam PKS (2001) Biomagnification of radiocesium in a top marine fish predator. Mar Ecol Prog Ser 222:227-237

Submitted: May 24, 2005; Accepted: December 22, 2005 Proofs received from author(s): March 24, 2006 